\title{
Young Mexican physical self - concept gender comparisons
}

\author{
María Del Carmen Zueck ${ }^{1}$, José René Blanco ${ }^{1}$, Judith Rodríguez-Villalobos ${ }^{1}$, Oswaldo Ceballos ${ }^{2}$, \\ Gustavo Álvarez ${ }^{1, *}$
}

${ }^{1}$ Faculty of Physical Culture Sciences, Autonomous University of Chihuahua, México

${ }^{2}$ Faculty of Sport Organization, Autonomous University of Nuevo León, México

\section{Email address:}

gustio77@hotmail.com (G. Álvarez)

\section{To cite this article:}

María Del Carmen Zueck, José René Blanco, Judith Rodríguez-Villalobos, Oswaldo Ceballos, Gustavo Álvarez. Young Mexican Physical Self - Concept Gender Comparisons. American Journal of Applied Psychology. Vol. 3, No. 3, 2014, pp. 62-65.

doi: 10.11648/j.ajap.20140303.13

\begin{abstract}
The purpose of the present study was to compare the profiles of physical self-concept between men and women high school Mexican students. A total sample of 709 participants, 324 women and 385 men, aged 13-19 years participated in this study. A quantitative approach with a descriptive and transversal survey design was used. All the participants completed the Physical Self-Description Questionnaire. Results of the one-way multivariate analysis of variance, followed by the one-way univariate analysis of variance, showed that in comparison among women, men obtained higher scores on the health, coordination, activity, sports competence, strength, flexibility, endurance, global physical self-concept and global self-esteem subscales. However, in the body fat and appearance subscales statistically significant differences were not found because of the differences between men and women in their perception of their physical self-concept, these findings suggest that in order to design any intervention for improving the perceived physical self-concept of the students, the variable gender should be taken into account.
\end{abstract}

Keywords: Physical Self-Concept, Student's Beliefs, Gender Differences, Self-Perception

\section{Introduction}

Psychology has always paid special attention to Self-concept. So it is not surprising that different definitions and explanations have been offered about its nature and background. One of the most accepted, diffusing and suggested multidimensional models comes from Shavelson, Hubner, and Stanton (1976) where the general concept occupies the upper part of the hierarchy divided into Academic Self-concept and Non-Academic Self-concept. The Self-concept of Non-Academic comprises the domains of the Social, Emotional, and Physical Self-concept (Marsh, 1987; Marsh \& Shavelson, 1985).

Multidimensional Nature of Physical Self - concept has certainly described about the widely acceptance among the psychological theories, however different proposals have been managed on which are its dimensions. In Shavelson et al. (1976) model, Physical Self-concept appears divided into self-perceptions of physical abilities and physical appearance, but later models as Marsh (1997) Physical Self-Description Questionnaire is the one which is the one adopted for this research, include a higher number of components, 9 components.

Self-concept plays a decisive and central role in the development of personality, such as it is highlighted in the main psychological theories. A positive Self-concept is the base of proper personal, social and professional performance depending on him to a large extent, his personal satisfaction and feeling fine with himself. In particular, Physical Self-concept proves to be a good indicator of mental health and life adjustment (A. Goñi, 2009; E. Goñi \& Infante, 2010; Reigal, Videra, Parra, \& Juárez, 2012). Feeling fine with our body helps generating positive feelings. So that achieving a positive Self-concept is one of the main pretended goals in large number of psychological intervention programs (Education, Clinical, Community, Civic...) for those who demand strategies and resources, which permit its improvement (Esnaola, Goñi, \& Madariaga, 2008).

In almost all the studies made by different authors, differences in gender were found. "Women" Self-concept is meaningfully inferior to "Man" (Cağlar, 2009; Cağlar \& 
Asci, 2006; Eitzen \& Sage, 1997; Pastor, Balaguer, \& García-Merita, 2003); where a possible explanation may be the fact of a socialization process in the physical practice of sports such as it happens in other development fields, where exists a stereotype which helps man to participate, in a special way, in competitive sports where they have the opportunity to develop certain physical skills more than women (Fernández, Contreras, González, \& Abellán, 2011; Rodríguez, González-Fernández, \& Goñi, 2013).

This Study is basically descriptive type, and pretends to compare the profiles of Self-concept among Mexican man and Mexican woman , high school and Junior high students, considering that in the last years, the Physical Self-concept has gotten a special popularity in modern societies, where most of them have created a whole subculture based on perception and the importance of an ideal image (Banfield \& McCabe, 2002).

As a consequence this study pretends, as an applied research, to contribute with information which is carried out to more quality of the Educational Practice in the context of attention to diversity; contributing to the pedagogical knowledge clearing up the different factors which form a holistic human development model. All this under the premise that all the Educational efforts should focus on the increase of Self-assessment feelings and students competence, strengthen Self-steem and Self-concept which will promote motivation toward success, interpersonal relationships and their particular way of developing themselves in different tasks and challenges presented to them.

\section{Method}

\subsection{Participants}

A sample of 709 high school Mexican students, 324 Women and 385 Men, aged 13-19 years ( $M=15.22$; $\mathrm{SD}=1.63$ ) participated in the present study. A convenience sampling was used in order to try covering the representative of different school levels studied.

\subsection{Instrument}

Physical Self-Description Questionnaire. This questionnaire consisted of 70 items that measure nine specific components of the physical self-concept (health, coordination, body fat, activity, sports competence, appearance, strength, flexibility and endurance) and two global components (global physical self-concept and global self-esteem). Its response format is based on a 6-point true/false Likert-type scale (higher scores indicating higher physical self-concept). The items have both positively and negatively worded questions. All negatively worded items (21 in total) are reverse scored and summarized with other scores of the correspondent scale. The PSDQ was translated into Spanish, followed by a back-translation procedure widely described in the literature (Marsh, Tomás, \& Abçý, 2002). Overall, the PSDQ accomplishes good internal consistency based on the extant empirical evidence. Mean reliability estimates within all subscales are above $\alpha=.8$, with the subscale Health presenting the lowest mean reliability estimate at $\alpha=.823$ and the subscale Body fat the highest at $a=.943$ (Schipkea \& Freund, 2012).

\subsection{Design}

Regarding the design of the study, a quantitative approach with a descriptive and transversal survey design was used (Hernández, Fernández, \& Baptista, 2010). The independent variable was gender (women and men) and the dependent variables were the scores on physical self-concept.

\subsection{Procedure}

The High school students were invited to participate in the present study. These students were fully informed about all the features of the project. Then, all the students that agreed to participate were asked to sign a written informed consent. After the students approvals were obtained, participants completed the above mentioned questionnaire by means of the instrument module administrator of the Scales Editor Version 2.0 (Blanco et al., 2013).

Participants completed the questionnaire in the computer rooms of their schools during a session. At the beginning of the session the researchers gave a general introduction about the importance of the research and how to access the questionnaire thought the software. When the participants were into the editor, the instructions about how to fill out the questionnaire correctly appeared before the instrument. Additionally, the participants were advised to ask for help if confused concerning either the instructions or the clarity of a particular item. Completion of the entire questionnaire took approximately 30 minutes. At the end of the session their participation was welcomed. Afterward, when all the participants completed the questionnaire, the data were collected by means of the results generator module of the Scales Editor Version 2.0 (Blanco et al., 2013).

\subsection{Data Analysis}

Descriptive statistics (means and standard deviations) for all the variables were calculated. Subsequently, after verifying that the data met the assumptions of parametric statistical analyses, a one-way multivariate analysis of variance (MANOVA), followed by the one-way univariate analysis of variance (ANOVA), were used to examine the differences between the men and women on the reported physical self-concept scores. Moreover, the effect size was estimated using the eta-squared $\left(\eta^{2}\right)$. All statistical analyses were performed using the SPSS version 20.0 for Windows (IBM $®$ SPSS $®$ Statistics 20 ). The statistical significance level was set at $p<.05$.

\section{Results}

Table 1 shows the mean values and standard deviations 
of the subscales of physical self-concept, as well as the results of the MANOVA and the follow-up univariate ANOVAs. The MANOVA results indicated overall statistical significant differences between genders on the physical self-concept scores (Wilks' $\lambda=.710 ; p<.0001 ; \eta^{2}$ $=.290$ ). Subsequently, the follow-up ANOVAs showed that compared with the women, the men obtained higher scores on the subscales health, coordination, activity, sports competence, strength, flexibility, endurance, global physical self-concept and global self-esteem. However, in the body fat and appearance subscales statistically significant differences were not found $(\mathrm{p}>.05)$.

\section{Discussion and Conclusions}

The achieved results shows that in most areas and factors of Physical Self-concept, man perceive themselves better than women. We can conclude that women show a lower developed Physical Self-concept; this conclusion coincides with similar studies (Cağlar, 2009; Fernández et al., 2011; Pastor et al., 2003) where it is also reported that women tend to show lower levels of Physical Self-concept than man; predisposing women to a higher risk of food disorders. It has been proved that people with poor Physical Self-concept are more vulnerable to cultural pressure of a more slim body (A. Goñi \& Rodríguez, 2004; E. Goñi \& Infante, 2010; Rodríguez et al., 2013).

These results can also been explained on basis in Western Cultural Gender Stereotypes, that man have more opportunities to develop physical activities and with these, improve their Physical Self-concept in a higher extent than women (Colley, Berman, \& Millingen, 2005; Contreras, Fernández, García, Palou, \& Ponseti, 2010). In other words, the process of socialization encourages determined ways of thinking, feeling and acting and depending on being a man or a woman promotes an identity of gender; this explains de development of believes differentiated among men and woman (Cağlar, 2009).

All found differences among men and women toward Physical Self-concept suggest that when designing any type of intervention with the aim of improvement, the variable of "gender" needs to be taken in consideration. Besides it is underlined the importance of doing further research of this issue in our country.

Table 1. Results of MANOVA for the gender differences on the eleven subscales of physical self-concept.

\begin{tabular}{cccccc}
\hline & $\begin{array}{c}\text { women } \\
(\boldsymbol{n}=\mathbf{3 2 4})\end{array}$ & $\begin{array}{c}\text { men } \\
(\boldsymbol{n}=\mathbf{3 8 5})\end{array}$ & $\boldsymbol{F}$ & $\boldsymbol{p}$ & $\boldsymbol{\eta}^{\mathbf{2}}$ \\
\hline health & & & 25.926 & $<.001$ & .290 \\
coordination & $3.60(0.73)$ & $3.76(0.76)$ & 8.418 & $<.001$ & .012 \\
body fat & $2.55(1.35)$ & $3.28(1.03)$ & 66.045 & $<.001$ & .085 \\
activity & $3.60(1.34)$ & $3.76(1.20)$ & 2.970 & .085 & .004 \\
sports competence & $2.03(1.44)$ & $3.23(1.24)$ & 143.511 & $<.001$ & .169 \\
appearance & $2.09(1.39)$ & $3.14(1.26)$ & 111.977 & $<.001$ & .137 \\
strength & $3.03(1.19)$ & $3.18(1.06)$ & 3.308 & .069 & .005 \\
flexibility & $2.22(1.04)$ & $3.11(1.03)$ & 129.933 & $<.001$ & .155 \\
endurance & $2.41(1.19)$ & $2.90(1.06)$ & 34.392 & $<.001$ & .046 \\
global physical self-concept & $1.62(1.15)$ & $2.81(1.18)$ & 183.731 & $<.001$ & .206 \\
global self-esteem & $3.02(1.58)$ & $3.93(1.09)$ & 80.422 & $<.001$ & .102 \\
\hline
\end{tabular}

Note. Descriptive values are reported as mean (standard deviation).

\section{Acknowledgements}

This study is part of a project funded by Mexican Ministry of Education-Department of Higher Education-General Directorate of the University Education [Secretaria de Educación Pública -Subsecretaría de Educación Superior-Dirección General de Educación Superior Universitaria de México] (OF-13-6894). Additionally, the first author is supported by a grant from the National Council of Science and Technology of Mexico (Conacyt).

\section{References}

[1] Banfield, S., \& McCabe, M. P. (2002). An evaluation of the construct of body image. Adolescence, Vol. 37(146), pp. 373-393.
[2] Blanco, H., Ornelas, M., Tristán, J. L., Cocca, A., Mayorga-Vega, D., López-Walle, J., \& Viciana, J. (2013). Editor for creating and applying computerise surveys. Procedia Social and Behavioral Sciences, Vol. 106, pp. 935-940. doi: http://dx.doi.org/10.1016/j.sbspro.2013.12.105

[3] Cağlar, E., \& Asci, F. H. (2006). Gender and physical activity level differences in physical self-perceptions of university students: a case of Turkey. International Journal of Sport Psychology, Vol. 37(1), pp. 58-74.

[4] Cağlar, E. (2009). Similarities and differences in physical self-concept of males and females during late adolescence and early adulthood. Adolescence, Vol. 44(174), pp. 407-419.

[5] Colley, A., Berman, E., \& Millingen, L. V. (2005). Age and Gender Differences in Young People's Perceptions of Sport Participants. Journal of Applied Social Psychology, Vol. 35(7), pp. 1440-1454. doi: 10.1111/j.1559-1816.2005.tb02178.x 
[6] Contreras, O. R., Fernández, J. G., García, L. M., Palou, P., \& Ponseti, J. (2010). Physical self-concept and its relationship to sports in adolescent students. Journal of Sport Psychology, Vol. 19(1), pp. 23-39.

Contreras, O. R., Fernández, J. G., García, L. M., Palou, P., \& Ponseti, J. (2010). El autoconcepto físico y su relación con la práctica deportiva en estudiantes adolescentes. Revista de Psicología del Deporte, Vol. 19(1), pp. 23-39.

[7] Eitzen, S., \& Sage, G. (1997). Sociology of North American sport. Dubuque, IA: Brown y Benchmark.

[8] Esnaola, I., Goñi, A., \& Madariaga, J. M. (2008). Self-concept: research perspectives. Psychodidactics Journal, Vol. 13(1), pp. 69-96.

Esnaola, I., Goñi, A., \& Madariaga, J. M. (2008). El autoconcepto: perspectivas de investigación. Revista de Psicodidáctica, Vol. 13(1), pp. 69-96.

[9] Fernández, J. G., Contreras, O. R., González, I., \& Abellán, J. (2011). Physical self-concept in high school education. Differences by gender and age. Revista Galego-Portugesa de Psicoloxía e Educación, Vol. 19(1), pp. 199-212.

Fernández, J. G., Contreras, O. R., González, I., \& Abellán, J. (2011). El autoconcepto físico en educación secundaria. Diferencias en función del género y la edad. Revista Galego-Portugesa de Psicoloxía e Educación, Vol. 19(1), pp. 199-212.

[10] Goñi, A., \& Rodríguez, A. (2004). Eating disorders, sports and physical self-concept in adolescents. Actas Españolas de Psiquiatría, Vol 32(1), pp. 29-36.

Goñi, A., \& Rodríguez, A. (2004). Trastornos de conducta alimentaria, práctica deportiva y autoconcep to físico en adolescentes. Actas Españolas de Psiquiatría, Vol 32(1), pp. 29-36.

[11] Goñi, A. (2009). The physical self: Psychology and education. Madrid: Pirámide.

Goñi, A. (2009). El autoconcepto físico: Psicología y educación. Madrid: Pirámide

[12] Goñi, E., \& Infante, G. (2010). Sport and physical activity, physical self-concept and life satisfaction. European Journal of Education and Psychology, Vol. 3(2), pp. 199-208.

Goñi, E., \& Infante, G. (2010). Actividad físico-deportiva, autoconcepto físico y satisfacción con la vida. European Journal of Education and Psychology, Vol. 3(2), pp. 199-208.

[13] Hernández, R., Fernández, C., \& Baptista, P. (2010). Research methodology. México: McGraw- Hill.
[14] Marsh, H. W., \& Shavelson, R. J. (1985). Self-concept: Its multifaceted, hierarchical structure. Educational Psychologist, Vol. 20(3), pp. 107-123.

[15] Marsh, H. W. (1987). The hierarchical structure of the self-concept: An application of hierarchical confirmatory factor analysis. Journal of Educational Measurement, 24, pp. 17-39.

[16] Marsh, H. W. (1997). The measurement of physical self-concept: A construct validation approach. In K. R. Fox (Ed.), The physical self. From motivation to well-being (pp. 27-58). Champaign: Human Kinetics.

[17] Marsh, H. W., Tomás, I., \& Abçý, H. (2002). Cross-cultural validity of the physical self-description questionnaire: comparison of factor structures in Australia, Spain, and Turkey. Research Quarterly for Exercise and Sport, Vol. 73(3), pp. 257-270. doi: 10.1080/02701367.2002.10609019

[18] Pastor, Y., Balaguer, I., \& García-Merita, M. L. (2003). Self-concept and self-esteem in middle adolescence: differential analysis by grade and gender. International Journal of Social Psychology, Vol. 18(2), pp. 141-159. doi: $10.1174 / 021347403321645258$

Pastor, Y., Balaguer, I., \& García-Merita, M. L. (2003). El autoconcepto y la autoestima en la adolescencia media: análisis diferencial por curso y género. International Journal of Social Psychology, Vol. 18(2), pp. 141-159. doi: $10.1174 / 021347403321645258$

[19] Reigal, R., Videra, A., Parra, J. L., \& Juárez, R. (2012). Sports physical activity, physical self-concept and psychological well-being in adolescence. Challenges. New tendencies in Physical Education, Sport and Recreation, 22, pp. 19-23.

Reigal, R., Videra, A., Parra, J. L., \& Juárez, R. (2012). Actividad físico deportiva, autoconcepto físico y bienestar psicológico en la adolescencia. Retos. Nuevas tendencias en Educación Física, Deporte y Recreación, 22, pp. 19-23.

[20] Rodríguez, A., González-Fernández, Ó., \& Goñi, A. (2013). Sources of perceived sociocultural pressure on physical self-concept. Psicothema, Vol. 25(2), pp. 192-198. doi: 10.7334/psicothema2012.229

[21] Shavelson, R. J., Hubner, J. J., \& Stanton, G. C. (1976). Self concept: Validation of construct interpretations. Review of Educational Research, 46, pp. 407-441.

[22] Schipkea, D., \& Freund, P. A. (2012). A meta-analytic reliability generalization of the Physical Self-Description Questionnaire (PSDQ). Psychology of Sport and Exercise, 13(6), 789-797. doi: http://dx.doi.org/10.1016/j.psychsport.2012.04.012 